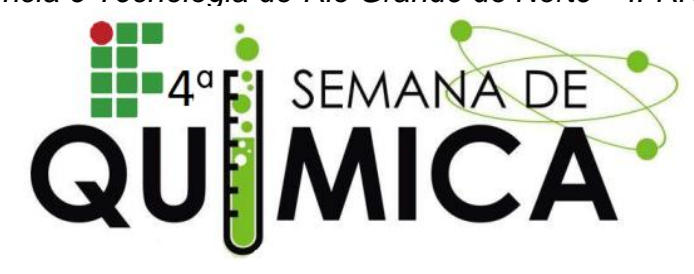

\title{
AVALIAÇÃO DA APLICABILIDADE DO AÇO COMO MATERIAL ESTRUTURAL NA CONSTRUÇÃO CIVIL
}

SILVA, C. R. A. (IFRN); BATISTA, B. K. C (IFRN); LEITE, I. M. (IFRN); DOS SANTOS, N. N. N. (IFRN)

Palavras Chave: Aço, Utilização, Vantagens

\section{INTRODUÇÃO}

No Brasil, a utilização do aço estrutural na construção civil vem crescendo continuamente; Embora seja mais recente e em menor proporção quando comparado aos países mais desenvolvidos. O setor de construção civil é o que mais consome aço no Brasil, respondendo em 2002 pelo consumo de mais de $32 \%$ do total produzido, sendo que somente $3 \%$ das construções são feitas em estruturas de aço. As figuras 1 (Arena do Morro em Natal/RN) e 2 (Estufa do Jardim Botânico em Curitiba/PR) mostram dois exemplos de construções metálicas no Brasil.

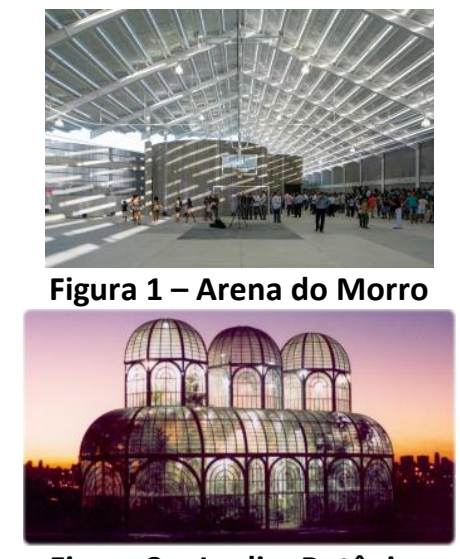

Figura 2 - Jardim Botânico

As principais vantagens apresentadas pelo sistema construtivo em aço são:

- Precisão construtiva;

- Maior área útil;

- Alívio de cargas nas fundações;

- Menor prazo de execução;

- Antecipação do ganho;

- Racionalização dos materiais;

- Garantia de qualidade;

- Reciclabilidade;

\section{METODOLOGIA}

Primeiramente foi adquirido referencial teórico. Em seguida foi elaborado um questionário e por meio das respostas dos profissionais entrevistados foi elaborado um diagnóstico.

\section{RESULTADOS E DISCUSSÕES}

Foram entrevistados nove profissionais da área técnica de edificações do campus SGA.

- Conhecimento de construções metálicas no Brasil: $78 \%$ conhecem e $22 \%$ desconhecem.

- Conhecimento das principais vantagens da utilização do aço como material estrutural na construção civil: $100 \%$ conhecem.

- Participação dos entrevistados em projetos de edificação envolvendo aço estrutural: $44 \%$ já participaram e $56 \%$ ainda não participaram.

- Principais justificativas citadas pelos entrevistados para o baixo percentual das construções metálicas no Brasil: alto custo do material, fator cultural e falta de conhecimento sobre o material.

\section{CONCLUSÃO}

O aço estrutural é um material versátil, eficiente, com excelente relação custobenefício e reciclável. Conforme diagnosticado neste trabalho, para que aumente consideravelmente seu uso na construção civil, são necessárias maiores divulgações das inúmeras vantagens desse material, bem como do sistema construtivo em aço, além de 
investimentos em capacitação para os profissionais da área.

\section{REFERÊNCIAS}

1 Lapefer. Disponível em: <http://www.Lapefer.com.br/hotsite/produtos _perfis_aplica.asp.>>. Acesso em 24 nov. 2014.

2 Construção Metálica. Disponível em: Acesso em 24 nov. 2014.

3 Aços Estruturais. Disponível em: . Acesso em 25 nov. 2014.

4 BANDEIRA, Adriana A. de Castro. Análise do uso de estruturas de aço em edificações habitacionais de interesse social. 2008. $122 \mathrm{f}$. Monografia (Especialização) - Curso de Construção Civil, Engenharia de Materiais e Construção, Universidade Federal de Minas Gerais, Belo Horizonte, 2008.

5 Crescimento e vantagens do uso do aço na Construção Civil. Disponível em: . Acesso em: 10 nov. 2014. 